\title{
Glasgow's new town hall: imperialism, nationalism and civic pride, 1877-1889
}

\author{
Miel Groten ${ }^{\star \dagger}$ (iD) \\ Faculty of Humanities, Department of Art \& Culture, History, and Antiquity, Vrije Universiteit \\ Amsterdam, De Boelelaan 1105, 1081 HV, Amsterdam, Netherlands \\ ${ }^{\star}$ Corresponding author. Email: m.p.groten@vu.nl
}

\begin{abstract}
Nineteenth-century Glasgow was widely imagined and presented as the proud 'Second City of the Empire'. This article investigates the implications of this identification with the empire by analysing Glasgow's great town hall, built $1883-89$, as the main manifestation of the city's civic pride. It shows how the building's architectural style, sculpture and inauguration ceremonies created a specific image of 'imperial' Glasgow which emphasized loyalty to Union and empire. Instead of undermining each other, the layered political allegiances of civic pride, nationalism, unionism and imperialism were mutually reinforcing, shaping the town hall still in use today.
\end{abstract}

' $[\mathrm{T}] \mathrm{o}$ promote with zeal and perseverance the highest and best interests of this great community and of the empire to which it belongs.' That was what in October 1889, Glasgow's Lord Provost James King hoped the city's new town hall would enable its municipal government to do. ${ }^{1}$ Coupling Glasgow's fortunes to the British empire's might seem a simple case of local chauvinism. However, in fact it was part of a widely held conviction that the city's population size and industrial power made it of imperial significance as the 'Second City of the Empire'. This article investigates how Glasgow's new town hall, erected between 1883 and 1889, mediated this status. It argues that besides local and imperial identities, the building's design and inauguration were equally characterized by nationalist ideology in the form of unionism confirming Scotland's place in the United Kingdom and the empire. Furthermore, the professed harmony between these layered political allegiances extended to Glaswegian society itself, represented in the context of the town hall as a harmonious, hierarchic community.

\footnotetext{
${ }^{\dagger}$ For providing useful comments on earlier versions in various settings, I would like to thank the two anonymous reviewers along with Ido de Haan, Gaard Kets, Henk te Velde and Richard Vinen; the staff of the city archives and special collections in Glasgow's Mitchell Library have been ever helpful.

${ }^{1}$ Glasgow Herald (GH), 8 Oct. 1889, 5.

(C) The Author(s), 2020. Published by Cambridge University Press. This is an Open Access article, distributed under the terms of the Creative Commons Attribution licence (http://creativecommons.org/licenses/by/4.0/), which permits unrestricted re-use, distribution, and reproduction in any medium, provided the original work is properly cited.
} 
Glasgow's town hall, called City Chambers after completion, is taken here as the clearest manifestation of the city's civic pride. Architecture has been described as the 'primary means' by which nineteenth-century urban elites in Britain stimulated the development of a civic culture. ${ }^{2}$ If museums and libraries promoted a certain cultured civility, town halls facilitated and symbolized urban political power and helped urban elites construct a city's identity as the 'exponent of the life and soul of the City'. ${ }^{3}$ The conception, design and decorations of Glasgow's town hall, and the civic spectacles surrounding its foundation and opening, constructed a specific image of Glasgow and invested the building with meaning.

A varied collection of sources is used to investigate the representations of the building and the city. Reports from the municipal bureaucracy concerning the building's design and minutes of relevant council meetings reveal the municipality's needs and concerns. Treatises on Glasgow by city officials and outside observers provide information on how the town hall and the city were presented, while local newspapers and articles in architecture journals give an insight into the building's design process. For the building's design, there is no better source than the building itself, but contemporary drawings provide a useful source as well.

The remainder of this article is dedicated first to an analysis of Glasgow's 'imperial' civic pride, after which it discusses how the town hall came into being and the different ways in which its architectural style, sculpture and the civic ceremonies surrounding its inauguration represented Glasgow. By way of an epilogue, before summarizing the findings in the conclusion, the article will briefly reflect on how political and social changes in the city made the building's representation of Glasgow, in a way, outdated soon after its completion.

\section{Introduction: 'Second City of the Empire'?}

It might seem counter-intuitive to connect the local and urban to the imperial. After all, modern imperialism was primarily a concern of Europe's national governments. However, this did not preclude more local, urban identifications with empire from flourishing. Studies of architecture and heritage have demonstrated that empire-related activities were very much localized in specific cities and sites in western Europe, from offices and factories to mansions, docks and mission colleges. ${ }^{4}$ Capitals such as London and Amsterdam developed into 'imperial cities', while in provincial cities, chambers of commerce and geographical societies embarked on a 'municipal imperialism' of their own. ${ }^{5}$ Contemporaries hailed cities

\footnotetext{
${ }^{2}$ K. Hill, “Thoroughly imbued with the spirit of ancient Greece". Symbolism and space in Victorian civic architecture', in A. Kidd and D. Nicholls (eds.), Gender, Civic Culture and Consumerism. Middle-Class Identity in Britain, 1800-1940 (Manchester and New York, 1999), 99-111, at 104.

${ }^{3}$ Charles Barry Sr, cited in A. Briggs, Victorian cities (Hardmondsworth, 1968 edn), 159; T. Hunt, Building Jerusalem. The Rise and Fall of the Victorian City (London, 2005), 243-4.

${ }^{4}$ G.A. Bremner, 'The metropolis. Imperial buildings and landscapes in Britain', in G.A. Bremner (ed.), Architecture and Urbanism in the British Empire (Oxford, 2016), 125-58; D. Hondius et al., Amsterdam Slavery Heritage Guide (Volendam, 2014); U. van der Heyden and J. Zeller (eds.), Kolonialismus hierzulande. Eine Spurensuche in Deutschland (Erfurt, 2007).

${ }^{5}$ F. Driver and D. Gilbert (eds.), Imperial Cities. Landscape, Display and Identity (Manchester, 1999); M. Wintle, 'Visualizing commerce and empire. Decorating the built environment of Amsterdam', in
} 
for their imperial ties, such as Portsmouth, 'gateway of the empire', Nantes, 'grand port industriel et colonial', or Hamburg, 'Herz für die deutschen Kolonien'.

Victorian Glasgow is another example, and histories of the city rarely fail to mention its 'Second City of the Empire' slogan as an expression of its welldeveloped civic pride. What fed its identification with empire was an immense economic entanglement with it, that had started with the eighteenth-century American and Caribbean trade. The 'second city' claim referred first to Glasgow's population size which, at 511,415 people in 1881 and 761,709 in 1901, only Birmingham and Manchester rivalled. ${ }^{7}$ Yet this demographic distinction was inherently connected to the city's economic progress and often referred to in the same breath. ${ }^{8}$ In the Victorian era, Glasgow developed into an industrial powerhouse and first-rank port with exceptionally strong trade and shipping links with the empire, particularly India. Best known for its engineering, shipbuilding and other heavy industries, but also home to important textile and chemical industries, Glasgow and its neighbouring communities along the river Clyde produced machinery, engines, locomotives and most famously ships, much of this destined for imperial and overseas markets. ${ }^{9}$ Shipbuilding especially appealed to the Victorian imagination, as its products both enabled and symbolized Britain's imperial might. ${ }^{10}$

By 1900, even municipal policy was coupled to the 'second city' slogan. Since about 1850, the municipal government had taken it upon itself to construct public parks, supply water, gas and later electricity, and to improve its police and public health organization. ${ }^{11}$ The resulting self-image of being a 'model' municipality was framed in imperial terms: by 1900, local publications held that Glasgow was 'the first municipality in the world and the second city in the British empire'

M. de Waard (ed.), Imagining Global Amsterdam. History, Culture, and Geography in a World City (Amsterdam, 2012), 76-82; J.F. Laffey, 'Municipal imperialism in nineteenth-century France', Réflexions historiques, 1 (1974), 81-114.

${ }^{6}$ Cited in B. Beaven, Visions of Empire. Patriotism, Popular Culture and the City, 1870-1939 (Manchester, 2012), 29; R. Aldrich, 'Colonialism and nation-building in modern France', in S. Berger and A. Miller (eds.), Nationalizing Empires (Budapest, 2015), 135-94, at 180-91; A. Coppius, Hamburgs Bedeutung auf dem Gebiete der deutschen Kolonialpolitik (Berlin, 1905), 176.

${ }^{7}$ J.M. MacKenzie, “The second city of the empire”. Glasgow - imperial municipality', in Driver and Gilbert (eds.), Imperial Cities, 215-37, at 215-16; C. Withers, 'The demographic history of the city, 1831-1911', in W. Hamish Fraser and I. Maver (eds.), Glasgow, vol. II: 1830 to 1912 (Manchester and New York, 1996), 141-62, at 142; see J. Nicol, Vital, Social, and Economic Statistics of the City of Glasgow (Glasgow, 1891), 12, 107; M.J.B. Baddeley, A Guide to Glasgow and its Environs (Glasgow, 1888), 17.

${ }^{8}$ Macaulay's Popular Illustrated Guide to Glasgow. Containing Six Beautiful Views of Interesting Places in Glasgow, and Map of the City (Glasgow, 1884), 10; Municipal Glasgow. Its Evolution and Enterprises (Glasgow, 1914), 2.

${ }^{9}$ M.S. Moss and J.R. Hume, Workshop of the British Empire (London and Edinburgh, 1977); S. Hazareesingh, 'Interconnected synchronicities. The production of Bombay and Glasgow as modern global ports c. 1850-1880', Journal of Global History, 4 (2009), 7-31; T.M. Devine, 'A Scottish empire of enterprise in the East, c. 1700-1914', in T.M. Devine and A. McCarthy (eds.), The Scottish Experience in Asia, c. 1700 to the Present (Cham, 2017), 23-49, at 36-9.

${ }^{10}$ D.R. Headrick, Tools of Empire. Technology and European Imperialism in the Nineteenth Century (Oxford and New York, 1981), 165-77; D. Burgess Jr, Engines of Empire. Steamships and the Victorian Imagination (Stanford, 2016).

${ }^{11}$ I. Maver, 'Glasgow's civic government', in Hamish Fraser and Maver (eds.), Glasgow, 441-85, at 453-68. 
and the 'exemplar of the cities of the Empire'. ${ }^{12}$ A carefully constructed image of responsible harmony among town councillors and civil servants underlay this claim, as did the dominance of Liberals on the council. ${ }^{13}$ Of course, Glasgow was not alone in expanding its municipal services, being particularly influenced by Birmingham and its 'civic gospel' which similarly determined its image under Joseph Chamberlain's mayoralty in the 1870 s. ${ }^{14}$ Nevertheless, the claim to imperial fame was typically Glaswegian.

However, if it is clear that Glaswegian civic pride drew on the British empire, this imperial dimension merits more critical attention. Civic cultures did not simply celebrate local government and economy, but were also a way of social control for the leading middle classes and helped to construct place identities against rival cities. ${ }^{15}$ Within Glasgow, a civic culture was constructed by the city's elite, centred around the town council and drawn mainly from the city's merchants, industrialists and professionals. Beyond Glasgow, the city competed with other major cities in the United Kingdom for prestige, including for the 'second city' title. If in other European states to be the country's second city could be an awkward distinction, to be the British empire's second city was an enviable supranational position, claimed with different arguments and at different moments also by the likes of Edinburgh, Dublin, Liverpool and Manchester. ${ }^{16}$ Britain's strong imperial culture clearly provided a fertile soil for such local identifications with empire. ${ }^{17}$ Yet nowhere was the claim as influential as in Glasgow, used consistently by both Glaswegians and outside observers for more than a century starting in the 1820s. ${ }^{18}$

To understand Glaswegian civic pride, it is necessary to investigate how an imperial outlook interacted with such national competition and local divisions, or, in other words, how local, national and imperial identities related to each other. In urban history, the relation between national and local identities is no longer seen as a zero-sum game but instead as an interplay between them, as the interests of the nation-state were increasingly translated into local terms and vice

\footnotetext{
${ }^{12}$ J.K. McDowell, The People's History of Glasgow (Glasgow, 1899), preface; Glasgow To-Day (Glasgow, 1909), 5.

${ }^{13}$ I. Maver, 'The role and influence of Glasgow's municipal managers, 1890s-1930s', in R.J. Morris and R.H. Trainor (eds.), Urban Governance. Britain and Beyond since 1750 (Aldershot and Burlington, 2000), 69-85, 69-71.

${ }^{14}$ I. Maver, 'Politics and power in the Scottish city. Glasgow town council in the nineteenth century', in T.M. Devine (ed.), Scottish Elites. Proceedings of the Scottish Historical Studies Seminar. University of Strathclyde 1991-1992 (Edinburgh, 1994), 98-130, at 121.

${ }^{15}$ J. Stobart, 'Building an urban identity. Cultural space and civic boosterism in a "new" industrial town. Burslem, 1761-1911', Social History, 29 (2004), 485-98.

${ }^{16} \mathrm{M}$. Umbach, 'A tale of second cities. Autonomy, culture, and the law in Hamburg and Barcelona in the late nineteenth century', American Historical Review, 110 (2005), 659-92; R.J. Finlay, 'National identity, union, and empire, c. 1850-1970', in J.M. MacKenzie and T.M. Devine (eds.), Scotland and the British Empire (Oxford, 2011), 280-316, at 294 n. 48; C. Wildman, Urban Redevelopment and Modernity in Liverpool and Manchester, 1918-39 (London and New York, 2016), 54-5.

${ }^{17}$ For the historiography of British imperial culture, see C. Hall and S. Rose (eds.), At Home with the Empire. Metropolitan Culture and the Imperial World (Cambridge, 2006); J.M. MacKenzie (ed.), The Victorian Vision. Inventing New Britain (London, 2001).

${ }^{18}$ MacKenzie, "'The second city of the empire".
} 
versa. ${ }^{19}$ In colonial history, the research into imperial cultures that post-colonial scholarship inspired has shown the extent of imperial ways of thinking in European societies' national self-images. ${ }^{20}$ As local and national identities were brought in line with each other, and in turn nationalism was entangled with imperialism, imperial concerns also 'trickled down' to the local level. Glasgow's civic pride exemplifies this interplay of layered identities, as the most imperialist exaltations of the new town hall and the city actually bore a strong nationalist stamp, often linked to the monarchy.

The addition of nationalism is complicated by Glasgow's position in Scotland, one of the United Kingdom's constituent 'four nations'. Nineteenth-century Scottish nationalism has been characterized by Graeme Morton as a 'unionist nationalism' that cherished Scotland's partnership with England in the Union, rather than striving for more autonomy. Lacking a state of its own, it played out in the local civil society of associations and municipalities. ${ }^{21}$ Scottish imagination of empire in the nineteenth century long remained rather provincial, Richard Finlay has argued, Scotland being subsumed simply under an imperial 'England'. Only after the 1886 Irish Home Rule debate did Scots start to imagine their share in the empire in more national terms when it became a 'conduit' for Scottish nationalism, exalted for the opportunities it provided. ${ }^{22}$ ' $[\mathrm{T}]$ he Union so bitterly opposed immediately opened up this promising and rapidly expanding field to the mercantile enterprise of Scotland', a later lord provost wrote in 1896, 'and soon colonial produce, sugar and tobacco, figured prominently on the trade lists of Glasgow'. ${ }^{23}$

The case of Glasgow City Chambers generally confirms this image but also offers some nuances. What wed Glasgow to the empire was its position in the United Kingdom, and the statements of political allegiance mediated by the town hall indeed expressed a British-imperial much more than a Scottish identity. However, the virtual absence of references to Scotland did not mean nationalism was lacking. The nationalism that connected Glasgow to the empire was rather an imperial-minded British nationalism, based on empire, monarchy and the general subscription to a liberal 'Whig' conception of history and society. ${ }^{24}$ Very comparable situations actually developed in Belfast and Cardiff in the other two 'Celtic' nations within the United Kingdom, where strong imperial identities based on these cities' role as industrial ports within the empire likewise trumped more strictly

\footnotetext{
${ }^{19} \mathrm{~V}$. Bickford-Smith, 'Introduction. The case for studying cities and nationalisms', Journal of Urban History, 38 (2012), 855-61; W. Whyte and O. Zimmer (eds.), Nationalism and the Reshaping of Urban Communities in Europe, 1848-1914 (Basingstoke, 2011).

${ }^{20}$ J.M. MacKenzie (ed.), European Empires and the People. Popular Responses to Imperialism in France, Britain, the Netherlands, Belgium, Germany and Italy (Manchester, 2011).

${ }^{21}$ G. Morton, Unionist Nationalism. Governing Urban Scotland, 1830-1860 (East Linton, 1999), 10-17, 43-8.

${ }^{22}$ Finlay, 'National identity', 284-301; I. McLean and A. McMillan, State of the Union. Unionism and the Alternatives in the United Kingdom since 1707 (Oxford, 2005), 10-11, 94-8.

${ }^{23}$ J. Bell and J. Paton, Glasgow. Its Municipal Organization and Administration (Glasgow, 1896), 6.

${ }^{24}$ C. Kidd, Subverting Scotland's Past. Scottish Whig Historians and the Creation of an Anglo-British Identity, 1689-1830 (Cambridge, 1993); W. Whyte, 'Building the nation in the town. Architecture and identity in Britain', in Whyte and Zimmer (eds.), Nationalism and the Reshaping, 204-33, at 222-3.
} 
national concerns. ${ }^{25}$ If the Home Rule debate would eventually put Scottish autonomy on the agenda, in Glasgow its immediate short-term effect was actually an added emphasis on Scottish and Glaswegian loyalty to Union and empire. Finally, when investigating the interplay of local, national and imperial identifications, distinctions have to be made between different groups or classes within British, Scottish or, in this case, Glaswegian society.

\section{A new town hall: requirements and architectural style}

A proud municipality needed a proud town hall. The expansion of Glasgow's municipal services and the continuous population growth meant the municipality's responsibilities constantly grew. To accommodate these, new municipal buildings had been built thrice already in the nineteenth century, most recently in 1870-74. Immediately, however, it was clear that this complex was too small. ${ }^{26}$ Therefore, in 1877, the town council appointed a committee to investigate the options for a completely new town hall 'in which the various departments of the city's service, under the administration of the magistrates and town council, may be carried on with efficiency and economy' ${ }^{27}$ City architect John Carrick, also in charge of the city's urban renewal projects, identified the eastern side of George Square as the best location. The square was a stone's throw from the existing town hall in Ingram Street in the fashionable western districts, and home to the brand-new post office (completed in 1876) and Merchants' House (1877). To its incipient 'civic' status added the many statues of local, Scottish and royal luminaries placed there over time, from James Watt and Walter Scott to Queen Victoria and Prince Albert. ${ }^{28}$

Besides providing office space, the building would also need to be 'handsome' and 'worthy', and include representative rooms for collective gatherings and festivities, needed for 'cultivating a spirit of good feeling between all classes and their Civic Rulers in the proper government of the City'. ${ }^{29}$ This was necessary if Glasgow was to maintain its position vis-à-vis 'the other important Municipalities of the Kingdom', which had indeed all erected new municipal buildings recently: Leeds, Liverpool, Bradford, Birmingham. ${ }^{30}$ But the most direct comparison was provided by Manchester where Alfred Waterhouse's town hall had just been completed. According to the Building News, Glasgow was 'about to follow the excellent example set her by her southern manufacturing rival', while the Glasgow Herald warned that Manchester's fine building need not be copied to 'obtain Municipal Buildings worthy the second city of the Empire. ${ }^{31}$

\footnotetext{
${ }^{25}$ Whyte, 'Building the nation', 222-5; C. Harvie, A Floating Commonwealth. Politics, Culture, and Technology on Britain's Atlantic Coast, 1860-1930 (Oxford, 2008), 80; J. Black, 'The United Kingdom and British empire. A figurational approach', Rethinking History. The Journal of Theory and Practice, 22 (2018), 3-24, at 13-15.

${ }^{26}$ Bell and Paton, Glasgow, 84.

${ }^{27}$ Mitchell Library, Glasgow (ML), Glasgow City Archives (GCA), box MP7/DTC 14.1.7, report by committee appointed on 13 Jul. 1877, 17 Sep. 1877, 177.

${ }^{28}$ R. McKenzie, Public Sculpture of Glasgow (Liverpool, 2002), 114-18, 122-31, 134-9.

${ }^{29}$ ML/GCA, MP7/DTC 14.1.7, report by John Carrick, 14 Sep. 1877, 177V.

${ }^{30}$ Ibid., 177.

${ }^{31}$ 'New municipal buildings for Glasgow', Building News and Engineering Journal, 33 (1877), 355; GH, 9 Aug. 1877, 3.
} 
It required two competitions to choose a design. For the first, in 1880, the London architect Charles Barry (Jr) was hired as an arbiter, and a design by the Leeds architect George Corson was selected. Corson described it as 'Palladian', and it drew inspiration from both Italian and French classical architecture. ${ }^{32}$ However, Barry felt the competition briefs requirements had been impossible to meet with the budget stipulated, which had caused him to exclude better designs just to stay within budget. This led to heated debates in the architecture journals, and an embarrassed town council ultimately decided on a second competition. ${ }^{33}$

The second competition's brief was similar to the first, and Barry again functioned as arbiter. A classical style was no longer compulsory but still preferable. ${ }^{34}$ It could hardly be otherwise, since it had long been the architectural style of choice in 'this Classical city. ${ }^{35}$ Rather than antiquarian, this was a modern and commercial taste, where classical forms were used eclectically to suit contemporary functions and were associated with republican virtues. ${ }^{36}$ Contrarily, the Gothic style of Manchester's town hall was 'a rock to be shunned' according to Lord Provost William Collins. ${ }^{37}$ Like the equally historicist but 'national' Scots Baronial style, Gothic was used in commercial buildings in Glasgow, but neither were considered serious candidates for its town hall. A further suggestion was given by the requirement that the building's inner courtyard would have to be accessible through 'a spacious opening similar to the entrance to Somerset House from the Strand, or to the Foreign Offices' ${ }^{38}$ Both were significant government buildings from the imperial metropolis, London, and that these examples were on the authorities' mind shows their pretensions and perspective. Eighteenth-century Somerset House was seen as British classical government architecture at its best, associated with Roman antiquity and civic values, while the Foreign and India Offices were a modern government office that symbolized Britain's political power overseas. They had been the subject of a fierce debate on architectural style, in which George Gilbert Scott was forced to rework his Gothic design into a classical version as that style was felt to represent dignified public values better. ${ }^{39}$

The two-tiered second competition attracted even more designs than the first (125 against 96), judged by Barry and Carrick, and was handled by town clerk James D. Marwick, who as the municipality's most powerful magistrate would also have the strongest opinion on its needs. ${ }^{40}$ In June 1882, the two architects

\footnotetext{
${ }^{32}$ National Library of Scotland, Edinburgh, Report Explanatory of Designs for Proposed Municipal Offices, Glasgow. Submitted under the Motto: 'Carton' (1880), 3; D.W. Walker, 'The Glasgow municipal buildings competitions, 1880-1882', University of St Andrews MA thesis, 1995, 35-6.

${ }^{33}$ Walker, 'The Glasgow municipal buildings competitions', 31-5, 47-61.

${ }^{34} \mathrm{ML} / \mathrm{GCA}$, DTC-6.31, outline of conditions for the second competition, 24 May 1881, 193.

${ }^{35}$ 'Glasgow municipal buildings competition', The Builder, 39 (1880), 315-17, at 315.

${ }^{36} \mathrm{~J}$. Schmiechen, 'Glasgow of the imagination. Architecture, townscape and society', in Hamish Fraser and Maver (eds.), Glasgow, 486-518, at 499-503.

${ }^{37} \mathrm{GH}, 7$ Apr. 1880, 9.

${ }^{38}$ ML/GCA, MP7/TC 14.1.7, report by John Carrick, 28 Apr. 1881, 189.

${ }^{39}$ G.A. Bremner, 'Nation and empire in the government architecture of mid-Victorian London. The Foreign and India Office reconsidered', Historical Journal, 48 (2005), 703-42.

${ }^{40} \mathrm{ML} / \mathrm{GCA}, \mathrm{D}-\mathrm{TC} 6 / 31$, award by assessors in competition, 7 Jan. 1882, 204.
} 
announced to the council that they had selected the design with the motto Viola, which combined 'artistic excellence' with sensible practical arrangements. ${ }^{41}$

The selected design was produced by William Young (1843-1900). Young, born in nearby Paisley but working from London since 1865, was unknown in the field of public buildings and instead had designed and remodelled mansions all over Britain for a profitable network of aristocratic clients. When he died in 1900, he was remembered for the 'grandeur of the scale' and 'stately halls and staircases' which he used. ${ }^{42}$

Glasgow's municipal building was no exception to this qualification, as can be judged from Figure 1. Its classical façades consisted of rusticated lower storeys, windows set between pediments and columns, corner pavilions with cupolas, an imposing central entrance underneath a pediment and a tall tower crowned by turrets and a lantern. Inside, the classical opulence continued with sumptuous staircases of colourful marble and alabaster and mosaic-clad corridors.

But in the building's style there were also specific Glaswegian concerns. Given that records of Barry's and Carrick's, and probably Marwick's, considerations have not survived, their exact appraisal of the designs submitted in the competition is unknown. The three runners-up they selected clearly had the general classical style, the emphasized corner pavilions, the tower and the extensive use of sculpture in common with Young's design. What seems to have set apart the latter were the more pronounced cupolas, the more monumental entrance and the clearer Italian inspiration. ${ }^{43}$ Young, who had recently studied the architecture of Rome, Florence and Venice in person, described the style as 'a free and dignified treatment of Italian Renaissance' inspired by these ancient cities. ${ }^{44}$ It was a typical case of nineteenth-century invention of tradition, and the illustrious republics of Venice and Rome were held up as examples for many a British city and its public buildings. ${ }^{45}$ Yet the title of 'Venice of the North' was perhaps carried farthest by Glasgow, where the Royal Exchange was nicknamed 'Glasgow's Rialto' and the tramways 'gondolas of the people'. 46 Many Italianate buildings in the cityscape articulated this claim: the aforementioned post office and Merchants' House, and the Venetian Gothic Stock Exchange (1877). ${ }^{47}$ Corson had also specifically referred to Venice for his cancelled design. ${ }^{48}$ And in 1894, a municipal committee that had travelled to the continent to find inspiration for the new building's banqueting hall murals specifically held up Venice as an example again. Even if its heydays were over, they wrote, its monuments 'remain to this moment and to all time fitting

\footnotetext{
${ }^{41}$ MLG/GCA, D-TC6/31, report by assessors on competition, 26 Jun. 1882, 209.

${ }^{42}$ J.M. Brydon, 'The late William Young', Journal of the Royal Institute of British Architects, 8 (1900), 448 , at 45 .

${ }^{43}$ Many competition entries are discussed in Walker, 'The Glasgow municipal buildings competitions'.

${ }^{44}$ Brydon, 'The late William Young', 46; W. Young, The Municipal Buildings Glasgow (London, 1890), 13-14, 17, 20-1.

${ }^{45} \mathrm{D}$. Cannadine, 'The context, performance and meaning of ritual. The British monarchy and the "invention of tradition", c. 1820-1977', in E. Hobsbawm and T. Ranger (eds.), The Invention of Tradition (Cambridge, 1983), 101-64, at 138; A. Briggs, Victorian Cities (London, 1963), 160-2; Hunt, Building Jerusalem, 227-43.

${ }^{46}$ I. Maver, Glasgow (Edinburgh, 2000), 124-5, 132.

${ }^{47}$ Ibid., 124-5.

${ }^{48}$ 'Proposed municipal buildings, Glasgow', The Builder, 39 (1880), 361.
} 


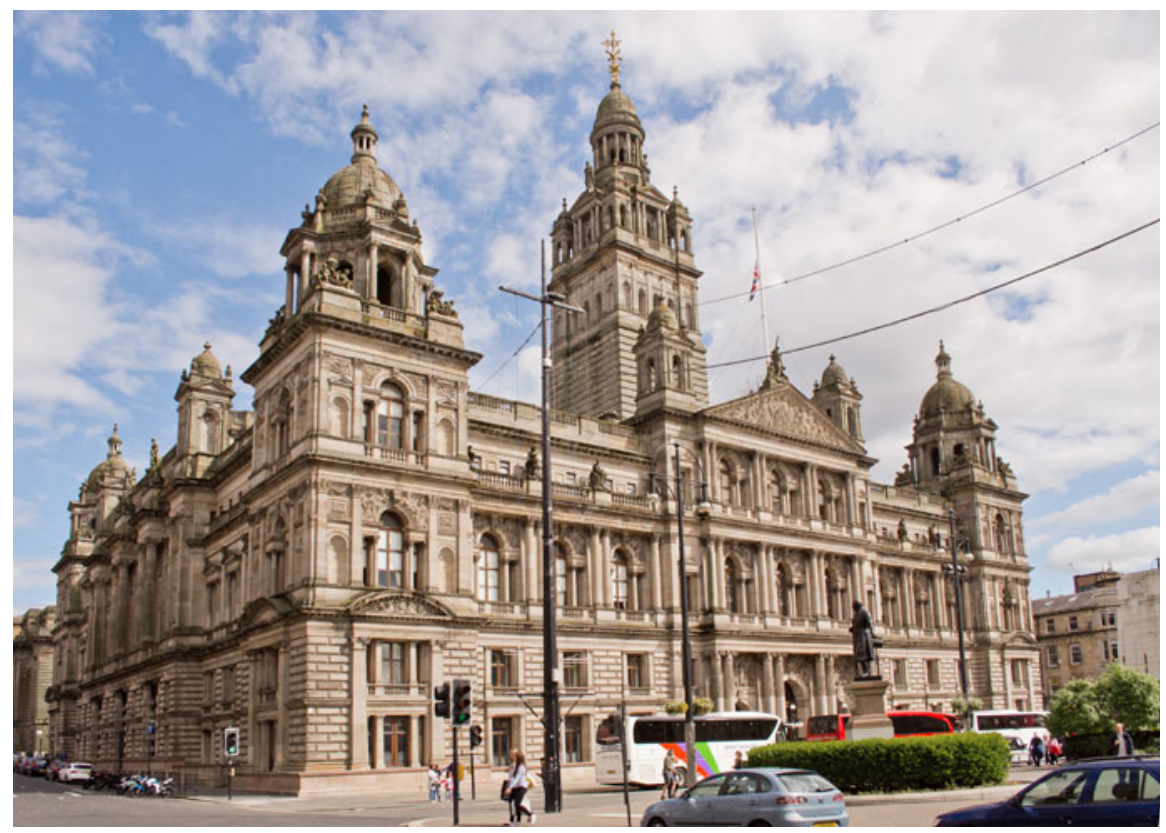

Figure 1. The City Chambers' George Square façade as it appears today. Photograph by the author, 2017.

memorials of the greatness of the people and of the liberal intelligence which accompanied their commercial and maritime predominance'. ${ }^{49}$ The comparison to Glasgow's 'liberal intelligence' and 'commercial and maritime predominance' was hard to miss.

The choice for monumental Renaissance classicism also had wider significance. Glasgow City Chambers was the first British town hall to employ this style and stylistically formed the turning point towards the Edwardian Baroque in British architecture, in vogue between 1895 and 1920. Well-suited for communicating political power, this pompous style was associated with the early modern 'national' English architecture of Christopher Wren and Inigo Jones. ${ }^{50}$ Because of these associations, it was 'perhaps the closest that Britain ever came to formulating an expressly "imperial" style of architecture', widely used in government and commercial buildings in Britain and the colonies, from Young's own War Office in Whitehall and Liverpool's Cotton Exchange to Durban city hall and the Hong Kong Supreme Court. ${ }^{51}$ It is telling that the town halls of Belfast and Cardiff, cities with similar imperial-industrial outlooks to Glasgow, would both be erected in this 'imperial' style as well. ${ }^{52}$ Like the Edwardian Baroque buildings it foreshadowed, the City Chambers used Renaissance architecture's imperial associations to profess not

\footnotetext{
${ }^{49}$ ML/GCA, MP26.102, report by sub-committee on banqueting hall decorations, 30 Aug. 1894.

${ }^{50} \mathrm{C}$. Cunningham, Victorian and Edwardian Town Halls (London, Boston and Henley, 1981), 152-4.

${ }^{51}$ Bremner, 'The metropolis', 150-1; G.A. Bremner, 'Stones of empire. Monuments, memorials, and manifest authority', in Bremner, Architecture and Urbanism, 87-124, at 98-100.

${ }^{52}$ Whyte, 'Building the nation', 224-5.
} 
only the city's power and affluence but also its loyalty to the United Kingdom and empire to which it owed its prominence. The Glasgow town hall was associated with Italian republicanism instead of English government, but the values it and the Edwardian Baroque conveyed were similar: loyalty, power, wealth, order.

\section{The Jubilee Pediment and Home Rule politics}

The large pediment over the main entrance would become the building's most explicitly imperial reference. Young had originally conceived it to portray 'Glasgow with the Clyde at her feet, sending her manufactures and arts to all the world'. ${ }^{53}$ Referring to the city and its commercial prowess, it would have made the city's ambitions clear enough and would have been more obviously imperial in nature than, for instance, Birmingham Council House's pediment which portrayed Britannia rewarding the city's manufacturers, and certainly more than Manchester's more local and Radical statues. ${ }^{54}$ However, the final design would become imperial in a different sense by its explicit support for the monarchy, the Union and the empire, exemplifying how a local civic identity was bound up with an imperial British identity. In November 1886, when the time came to agree upon a final design for the pediment, Young proposed to turn the pediment instead into 'a most important imperial memorial' of Queen Victoria's golden jubilee celebrated the next year. ${ }^{55}$ It would depict the queen surrounded by her 'subjects from the four quarters of the world coming to pay her homage', first England, Scotland, Ireland and Wales, and then Britain's colonies. ${ }^{56}$ According to Young, the building provided the country's and perhaps the world's only opportunity to construct such a unique and 'truly imperial' monument. ${ }^{57}$ The municipal building committee agreed, and in January 1887 approved of a clay model Young had produced. $^{58}$

Cities all over Britain and the empire were falling over each other to erect monuments to Victoria in $1887 .{ }^{59}$ But Young was right that none had the Glasgow elite's opportunity to associate their city government with the monarchy so explicitly and to transform their monument to municipal rule into a monument to imperial rule at the same time. Their convictions about Glasgow's and Scotland's place in Britain and the empire became more salient with the Irish Home Rule controversy. In early 1886, Liberal Prime Minister William Gladstone had unexpectedly introduced a 'home rule' bill to give Ireland its own parliament. The Conservatives and dissenting Liberals of his own party defeated the bill in parliament, which led not only to new elections that brought to power the Conservatives, but also to a split in Gladstone's Liberal party. Liberals who disapproved of Home Rule formed a loose grouping of 'Liberal Unionists' under the leadership of Joseph

\footnotetext{
${ }^{53} \mathrm{GH}, 4$ Oct. $1883,4$.

${ }^{54}$ T. Wyke, Public Sculpture of Greater Manchester (Liverpool, 2004), 24-32.

${ }^{55}$ ML/GCA, MP16, minutes of municipal buildings committee, 22 Nov. 1886, 433.

${ }^{56} \mathrm{GH}, 3$ Dec. 1886, 4.

${ }^{57}$ Ibid.

${ }^{58}$ MLG/GCA, MP16, minutes of municipal buildings committee, 19 Jan. 1887, fol. 434v.

${ }^{59}$ M. Droth, J. Edwards and M. Hatt, Sculpture Victorious. Art in an Age of Invention, 1837-1901 (Chicago, 1998), 102-13.
} 
Chamberlain. ${ }^{60}$ In Scotland, the issue was consistently understood in imperial terms, commentators writing about 'unity or disintegration of the Empire' and how Gladstone's defeat had 'saved the Empire'. 61

The issue was to have repercussions in Glasgow too. The local Liberals split, weakening the party's dominance on the town council. For those Liberals who already disagreed with the dominant 'Gladstonian' standpoints on topics such as temperance and church disestablishment, but who had closed ranks up to then, the party's conversion to Home Rule now caused definite alienation. ${ }^{62}$ In addition, there was also a dimension of social background, if not class. Many local industrialists feared Irish Home Rule would negatively impact the city's economy, and a number of affluent Liberals joined the Unionists. ${ }^{63}$ Conversely, amongst the city's more middle- and working-class population, Irish Home Rule and Gladstone enjoyed considerably more support. ${ }^{64}$

In this context, the pediment, as an explicit monument to the United Kingdom and empire, hit a nerve. It symbolized the harmony so essential to the 'second city' image - Glasgow in the empire, the empire in Glasgow. Conservative councillor James MacLennan reacted to Young's proposal that in these days of Home Rule it was very important that such a memorial...should be erected on the Municipal Buildings of one of the greatest corporations in the Empire. ${ }^{65}$ When the time came for the town council to vote on the pediment all Conservatives voted in favour, as did most Liberal Unionists. In contrast, 10 out of 15 of the council's 'Gladstonian' Liberals voted against, mainly the evangelical, pro-temperance middle-class councillors. ${ }^{66}$ They cited practical objections, such as the costs and bad visibility of the pediment, and denied their preference had anything to do with 'loyalty'. ${ }^{67}$ Yet for their opponents, the pediment's political symbolism outweighed such disadvantages: the final tally was 22 in favour, 13 against. ${ }^{68}$ In fact this seems to have been one of the few moments when there was debate over the costs, which might indicate that those opposing the pediment indeed had some ulterior motive. Against the $£ 520,000$ that the building would eventually cost ('only' half of Manchester's town hall), the $£ 1,500$ for the pediment sculpture seems not that extravagant. ${ }^{69}$

In its final form, the pediment (see Figure 2) depicted Queen Victoria accompanied by representations of England, Scotland, Ireland and Wales, surrounded by

\footnotetext{
${ }^{60}$ McLean and McMillan, State of the Union, 105-11.

${ }^{61}$ Cited in N. Lloyd-Jones, 'Liberalism, Scottish nationalism and the Home Rule crisis, c. 1886-93', English Historical Review, 129 (2014), 862-87, at 870.

${ }^{62}$ I. Sweeney [Maver], 'The municipal administration of Glasgow, 1833-1912. Public service and the Scottish civic identity', University of Strathclyde Ph.D. thesis, 1990, 632, 773.

${ }^{63}$ D. Howell, British Workers and the Independent Labour Party 1888-1906 (Manchester, 1983), 139.

${ }^{64}$ Ibid., 139-41; J.J. Smyth, Labour in Glasgow, 1896-1936. Socialism, Suffrage, Sectarianism (East Linton, 2000), 21.

${ }^{65} \mathrm{GH}, 3$ Dec. 1886, 4.

${ }^{66}$ MLG/GCA MP16, council meeting minutes, 22 Nov. 1886, fol. 434v. Political allegiances were taken from councillors' biographies in Sweeney, 'The municipal administration of Glasgow'.

${ }^{67}$ Evening News and Star, 3 Feb. 1887, 2; GH, 4 Feb. 1887, 10.

${ }^{68} \mathrm{ML} / \mathrm{GCA}$, council meeting minutes, 22 Nov. 1886.

${ }^{69} \mathrm{Nicol}$, Vital, Social, and Economic Statistics, 106-7.
} 


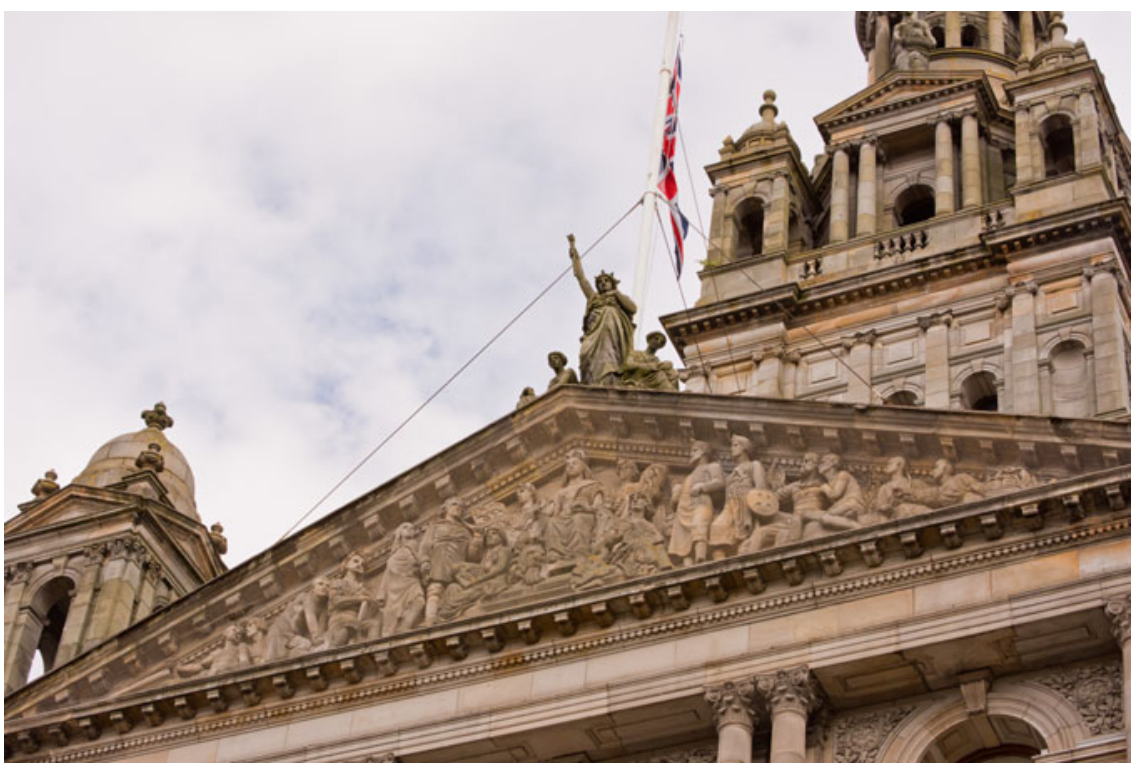

Figure 2. Close-up of the Jubilee Pediment. Photograph by the author, 2017.

[o]n one side Canada...an American Indian being introduced; Australia is shown by a gold digger; New Zealand by a female figure suggesting agriculture, with sheep and cattle about her, and there are numerous other carvings representing the other colonies of the empire, to the west of Great Britain. At the other side of the pediment are sculptures of East Indians, a native chief being one of the subjects, with the head and front of an elephant shown behind. After India comes Africa, symbolized by a white man having his arm round the neck of a negro. Further on, and extending out to the end of the pediment, our Mongolian and other dependencies to the east of Europe are indicated. ${ }^{70}$

This explicitly imperialist image centred around Queen Victoria, crowned empress a decade before, was very contemporary, although the general scheme of allegorical representations of exotic regions had a long pedigree in European art. The pediment exemplifies Victoria's increased popularity as 'mother' of the empire and the growing popular imperial culture in this period, as the sculptural equivalent of other representations of the empire such as propaganda maps. ${ }^{71}$ The way the 'Indian' and 'negro' were physically guided towards the figure of Victoria alluded to the idea of a civilizing mission, and the grouping of Canada, Australia and New Zealand on one side and Indian, African and 'Mongolian' subjects on the other emphasized a white British kinship within the larger empire.

\footnotetext{
${ }^{70}$ Ibid., 397.

${ }^{71} \mathrm{~F}$. Driver, 'In search of the imperial map. Walter Crane and the image of empire', History Workshop Journal, 69 (2010), 146-57; Cannadine, 'Context, performance and meaning', 124-5, 133.
} 


\section{Whose city? Representing the city's trades}

The town hall's monumental appearance was reinforced by an extensive sculptural programme that added to the message that the building communicated. There were generic classical motifs, and many allegories of bourgeois civic values that were more or less standard for public buildings: Faith, History, Harmony, Peace. ${ }^{72}$ But the spandrels over the second-storey Venetian windows on the George Square façade were home to sculpture 'representative of the trades carried on in the city and neighbourhood', carried out by Glasgow's most prominent sculptor John Mossman. ${ }^{73}$ The mostly female figures around the main entrance allegorically depicted chemistry, navigation, municipal government, commerce and shipping. On the other spandrels, male figures with attributes typical of certain professions depicted different trades associated with Glasgow.

Unlike the generic allegories, these reliefs depicted actual professions. Sculpture like this was purposely moralistic, part of a wider trend of employing sculpture to educate a mass urban audience. ${ }^{74}$ If the exact associations of the building's architectural style would have been 'legible' mostly to the initiated, these reliefs sent a more explicit message. As such, they reveal something about what social groups the civic elite included in their vision of Glasgow. Whose city was it that was the empire's second?

Ostensibly the sculpture represented Glasgow's industries, but the sculpture referred as much to the city establishment as to the working class. Mossman seems to have based his spandrels on the city's 14 'incorporated trades'. These historic associations made up the Trades' House, the craftsmen's equivalent of the Merchants' House mentioned above. The two guilds had governed the city before 1833 and since then had become sociable and philanthropic institutions of a still very elite nature: their heads functioned as town councillors and incorporation membership was a prerequisite to becoming a city official. ${ }^{75}$ All incorporations were included in the sculpture, including for instance the Cordiners, Bakers, Masons and Barbers. Two spandrels that symbolized engineering and shipbuilding together accounted for the Hammermen or metalworkers, testament to these industries' importance. Only the printing industry depicted in one spandrel did not correspond to an incorporation. On the corner pavilions, 16 small panels with sculpted tools repeated the representation of the incorporated trades. ${ }^{76}$

This scheme selectively represented the city and its economy. Young stated that the sculpture simply represented Glasgow's 'various trades and industries' ${ }^{77}$ And certain workers, such as bakers or masons, or those in the engine- or shipbuilding industries, could indeed identify with 'their' spandrel. Yet some of the other depicted trades, such as gardening and hairdressing, were of marginal importance and were included only by virtue of belonging to the incorporated Gardeners and Barbers, respectively. Furthermore, those of important but unskilled professions -

\footnotetext{
${ }^{72}$ McKenzie, Public Sculpture, 153, 155, 157.

${ }^{73}$ Ibid., 154-5, 493; GH, 18 Sep. 1886, 4.

${ }^{74}$ Schmiechen, 'Glasgow of the imagination', 490-9.

${ }^{75}$ Maver, 'Glasgow's civic government', 443-4.

${ }^{76} \mathrm{GH}, 3$ Dec. 1886, 4.

${ }^{77}$ Young, The Municipal Buildings, 17.
} 
porters, the tens of thousands mainly female workers in the textile industry, let alone the city's 10,000 'general labourers' - were excluded. ${ }^{78}$ The sculpture reinforced the blurred but important line between 'skilled' and 'unskilled' work that ran through the city's workforce, certainly if one realizes that precisely the shipbuilding and engineering industries were dominated by a small group of proud skilled workers. ${ }^{79}$

The architectural style of the building represented Glasgow as a centre of commercial and maritime power, while the Jubilee Pediment underlined the city's imperial loyalty and outlook. The George Square spandrels explicated what kind of city it was that was such a centre and had such an outlook: a city of just local government and dutiful skilled workers, hierarchically linked by traditional craft associations. This portrayal shows how Glasgow's civic elite constructed the 'second city' image in top-down fashion. If it seems rather inward-looking for a city with imperial aspirations - there were no personifications of foreign continents, no symbolic representations of the city's trading partners - this underlines that the imperial dimension of Glasgow's civic pride was primarily about the city's generic traits of a large population size, a massive industrial economy and a 'model' urban government.

Civic ritual was another way in which the building was invested with certain meanings, one in which the ordinary population of Glasgow could align themselves with the new building more autonomously. Civic ritual shared with historicist architecture and sculpture its 'invented' nature, but allowed for much more participation. Through its recreational value, civic ritual turned the audience into active participants, and workers' processions were commonly incorporated as signs of order and loyalty. ${ }^{80}$ In Glasgow, the foundation stone was laid down in 1883, while Queen Victoria officially opened the building in 1888 . These events more or less repeated in performance what the spandrel reliefs and the Jubilee Pediment represented in stone: respectively, a representation of the city's social and economic life that stressed its harmonious nature, and an expression of loyalty to the monarch. Again, the nationalist meaning of the latter gave rise to much more explicit invocations of the empire and Glasgow's place in it.

The laying of the foundation stone in October 1883 was accompanied by a 'civic and masonic' procession of the city's magistrates and dozens of Scottish masonic lodges, but also by a 'monster procession of the trades' of some 30,000 strong. ${ }^{81}$ Leaving, respectively, from the cathedral and from the Glasgow Green, a traditional working-class gathering place, both processions marched to George Square before an audience of allegedly some 500,000 spectators. On the square, Lord Provost John Ure ceremonially laid the foundation stone. ${ }^{82}$

\footnotetext{
${ }^{78}$ Ninth Decennial Census of the Population of Scotland, 1881, vol. II (Edinburgh, 1883), 707-14.

${ }^{79}$ W. Hamish Fraser, 'The working class', in Hamish Fraser and Maver (eds.), Glasgow, 300-51, at 319-21.

${ }^{80} \mathrm{~B}$. Roberts, 'Entertaining the community. The evolution of civic ritual and public celebration, $1860-$ 1953', Urban History, 44 (2017), 444-63; S. Gunn, 'Ritual and civic culture in the English industrial city, c. 1835-1914', in Morris and Trainor (eds.), Urban Governance, 226-41, at 229-33.

${ }^{81}$ Description of Ceremonial on the Occasion of Laying the Foundation Stone of the Municipal Buildings, in George Square, Glasgow (Glasgow, 1885), 2-3.

${ }^{82}$ Ibid., $2,4$.
} 
The 'Trades of the City and District' had initiated their participation themselves, though it is unclear how exactly - the fact their representatives met with the municipal committee overseeing the proceedings suggests close co-operation. ${ }^{83}$ The popularity of the event suggests widespread interest, and although the procession was undoubtedly an expression of working-class civic pride, the image of Glasgow it presented did not differ that much from the message conveyed by the spandrel sculpture. There were similar lines of exclusion and a similar emphasis on the orderly organization of labour. Per usual, the procession was an all-male affair, and the delegations represented their union, or in some cases firm, more than their profession as such. ${ }^{84}$ Since trade unions were still mainly for skilled workers at this time, this again prioritized skilled and organized over unskilled labour. ${ }^{85}$ Furthermore, as with the sculpture, the procession contained little explicit imperial rhetoric. Shipbuilders were present in force, thousands of them forming some of the parade's largest groups. ${ }^{86}$ Yet the procession was mainly a local affair, representing local trades more than a clearly defined image of the city.

In contrast, the ceremonial of 1888 conveyed many more imperial messages. Like the Jubilee Pediment, the relation to the monarchy made this a markedly more nationalist and imperialist event. In the summer of 1888, Glasgow organized a large international exhibition where hundreds of British and international firms presented their wares, with Glaswegian companies, notably the Clydeside shipbuilders, taking centre stage. ${ }^{87}$ Many colonial firms contributed to the exhibition too, particularly those connected to India due to Glasgow's strong trade relations with the region. ${ }^{88}$

Victoria visited the exhibition in August, and accepted the municipality's request to open the new town hall officially as it was nearing completion. As city chamberlain James Nicol put it, Victoria's jubilee and visit together formed 'an epochmaking term' for Glasgow, celebrating a reign 'unexampled for the expansion and development in material greatness of our Empire, and in the...means and appliances for drawing all parts of the Empire and the entire world closely together. ${ }^{89}$ It was well understood that Glasgow had contributed its fair share to the production of these means and appliances.

The queen arrived in Glasgow on 22 August and travelled to the courtyard of the municipal buildings. Here, town clerk Marwick read an address to her in which he drew attention to the Jubilee Pediment. ${ }^{90}$ In fact, she had already seen it in photographs that the municipality had sent along with its official felicitations earlier that

\footnotetext{
${ }^{83}$ MLG/GCA, MP9-DTC/14.1.9, report by committee on foundation stone arrangements, 4 Mar. 1884, 2; MLG/GCA, MP12, invitation by lord provost for meeting with municipal committee, 30 Aug. 1883, 713.

${ }^{84} \mathrm{~S}$. Gunn, The Public Culture of the Victorian Middle Class. Ritual and Authority in the English Industrial City 1840-1914 (Manchester and New York, 2000), 174; Description of Ceremonial, 19-41.

${ }^{85} \mathrm{~W}$. Hamish Fraser, Trade Unions and Society. The Struggle for Acceptance 1850-1880 (Totowa, NJ, 1974), 208-10.

${ }^{86}$ Description of Ceremonial, 41.

${ }^{87}$ P. Kinchin and J. Kinchin, Glasgow's Great Exhibitions, 1888, 1901, 1911, 1938, 1988 (Wendlebury, 1988), 18-19.

${ }^{88}$ Ibid., 17-53.

${ }^{89}$ Nicol, Vital, Social, and Economic Statistics, 388-9.

${ }^{90}$ Ibid., 427.
} 
summer. ${ }^{91}$ Victoria gave a brief reply in which she officially opened the building, and the party then moved to the exhibition grounds. Attendance was again very high as allegedly over 700,000 persons had gathered to witness the queen. ${ }^{92}$ Near the exhibition, Victoria was met by 'Lascars from vessels that run between London \& Glasgow, all dressed in white, with scarlet sashes and turbans'. ${ }^{93}$ They were employees of the Clan and Anchor shipping lines that had their head office in the city. ${ }^{94}$ Indian sailors were a relatively new 'imperial' presence in Glasgow as the Clyde had long been too narrow for large steamships. Mobilizing them to welcome the queen-empress was thus both a way to add colonial lustre to her visit and a reminder of the city's recent economic development. ${ }^{95}$

Generally, both ceremonies were comparable to civic ritual in other major cities, whether the opening of Leeds town hall by Victoria in 1858, the trades processions celebrating the opening of Bradford's town hall in 1873 and Manchester's in 1877, or the many inaugurations of public buildings in Edinburgh by councillors in the 1870s and 1880s. ${ }^{96}$ However, what set Glasgow apart, in a way, was that it combined all of the above. At Leeds, there was no trades procession yet; at Manchester no queen to open the building, probably dissuaded by Prime Minister Disraeli who disliked the city's radicalism, and its trades procession apparently drew only 66,000 spectators; at Edinburgh, there was no new town hall to celebrate as the centrepiece of civic pride. ${ }^{97}$ The Glasgow city elite could pride themselves on this distinction, confirming their vision of a loyal and well-governed city favoured by the queen herself.

\section{Epilogue: class and contestation}

The 1888 celebrations formed a successful initiation for the new building, that was put in use one year later and has functioned as the seat of local government since. However, retrospectively the celebrations were not only the high point, but in a way also the beginning of the end of the idealized 'second city' image that the building embodied. For despite the enthusiastic crowds, and unlike the rather compliant show of 1883, in 1888 for the first time some very small but significant dents were being made in the civic elite's image of Glasgow as a harmonious, confident city. Crowds jeered at the Yeomanry Cavalry, part-time 'fireside soldiers' drawn

\footnotetext{
${ }^{91}$ MLG/GCA, MP16, council meeting minutes, copy of letter by town clerk Marwick to private secretary Ponsonby, 1 Jun. 1887, 342-4; copy of letter by Ponsonby to Marwick, 4 Jun. 1887, 347.

${ }^{92} \mathrm{Nicol}$, Vital, Social, and Economic Statistics, 426.

${ }^{93}$ Diary entry by Queen Victoria, 22 Aug. 1888, 47, www.queenvictoriasjournals.org, accessed 17 Jan. 2019.

${ }^{94} \mathrm{GH}, 23$ Aug. 1888, 9.

${ }^{95}$ E.W. McFarland, 'Clyde opinion on an old controversy. Indian and Chinese seafarers in Glasgow', Ethnic and Racial Studies, 14 (1991), 493-515.

${ }^{96}$ Briggs, Victorian Cities (1963), 170-7; 'The Bradford trades procession', The Builder, 31 (1873), 723; W.E.A. Axon, Description of the Town Hall, Manchester, to which Is Added a Report of the Inaugural Proceedings, September 1877 (Manchester and London, 1878), 70-87; R. Rodger, "The "common good" and civic promotion: Edinburgh 1860-1914', in R. Colls and R. Rodger (eds.), Cities of Ideas. Civil Society and Urban Governance in Britain 1800-2000 (Aldershot, 2004), 144-77, at 153-8.

${ }^{97}$ Whyte, 'Building the nation', 207; J.J. Parkinson-Bailey, Manchester. An Architectural History (Manchester and New York, 2000), 112.
} 
from the upper and middle class, escorting the queen. ${ }^{98}$ And at the Glasgow Green, a counter-demonstration was organized by Robert Cunninghame Graham, elected two years earlier as the United Kingdom's first socialist MP for a nearby constituency. ${ }^{99}$ It was a Home Rule demonstration presided over by John Ferguson, Glasgow's pro-labour Irish leader, where Cunninghame Graham also protested against the monarchy and Glasgow's town councillors. The demonstration was relatively small, attracting a few hundred people. ${ }^{100}$ Yet as a contestation of the elite's idealized vision of Glasgow as a prosperous urban republic loyal to Union and empire, it pointed to the direction local politics would take in the decades to come. Slowly but steadily, from the late 1880s an independent political Labour movement developed that contested the Liberal dominance. In the early twentieth century, in the context of economic uncertainty this would coincide with a waning of municipal confidence in Glasgow, a more pessimistic vision on Union and empire in Scotland, and a general decline of urban civic cultures in Britain. ${ }^{101}$

These changes also impacted on the City Chambers. The aforementioned murals for which the committee toured the continent were realized around 1900, and now some did refer to Scotland. ${ }^{102}$ More importantly, this came from the working population for whom the town hall became a symbol of the political establishment in times of hardship. In 1908, hundreds of unemployed persons invaded the building and, allegedly singing a song 'The Red Flag', tried to enter the council chamber. ${ }^{103}$ When in 1914, King George V and Queen Mary laid the foundation stone of the building's extension, the Labour councillors refused to attend and leading socialist newspaper Forward ridiculed the 'Royal Hypnotist and Amateur Bricklayer'. ${ }^{104}$ Finally, the 1919 'Battle for George Square' saw a strikers' demonstration escalate into a violent riot which led the British government to send in the military. It heralded an image of Glasgow radically different from that of 'Second City of the Empire': now, it was seen as the heart of a militant 'Red Clydeside' fallen victim to socialism, the 'cancer of empire.. ${ }^{105}$

\section{Conclusion}

Glasgow City Chambers formed the most conspicuous manifestation of Glaswegian civic pride in the late nineteenth century that articulated the self-image of being the

\footnotetext{
${ }^{98}$ The Glasgow Evening News (GEN), 23 Aug. 1888, 4; G. Hay, The Yeomanry Cavalry and Military Identities in Rural Britain, 1815-1914 (Cham, 2017), 92-3.

${ }^{99}$ S. Howe, 'Anti-colonialism in twentieth-century Scotland', in B.S. Glass and J.M. MacKenzie (eds.), Scotland, Empire and Decolonisation in the Twentieth Century (Manchester, 2015), 113-30, at 113-14.

${ }^{100}$ GEN, 23 Aug. 1888, 4; GH, 23 Aug. 1888, 7; Smyth, Labour in Glasgow, 133-4.

${ }^{101}$ T. Hart, 'Urban growth and municipal government. Glasgow in a comparative context, 1846-1914', in A. Slaven and D.H. Aldcroft (eds.), Business, Banking and Urban History. Essays in Honour of S.G. Checkland (Edinburgh, 1982), 193-219, at 210-13; Finlay, 'National identity', 301-15; Gunn, The Public Culture, 187-99.

${ }^{102}$ C.A.P. Willsdon, Mural Painting in Britain 1840-1940. Image and Meaning (Oxford and New York, 2000), 184-5.

${ }^{103}$ Scotsman, 4 Sep. 1908, col. 5g.

${ }^{104}$ Daily Herald, 8 Jul. 1914, col. 1b; Forward, 11 Jul. 1914, col. 1c-d.

${ }^{105}$ W. Bolitho, Cancer of Empire (London and New York, 1924).
} 
'second city' of the British empire. The building's architecture signalled this identity as one that was powerful, loyal, large and prosperous. The city's civic elite, consisting of councillors, officials and the business community they were largely drawn from, understood and represented these local qualities as part of, and enabled by, a larger British imperial world.

The ideologies of civic pride, nationalism and imperialism mutually reinforced one another - in many ways, this article has disentangled what in fact were very much entangled phenomena. Yet in this context, the British-imperial identification overshadowed invocations of Scottishness as the town hall became a symbol of the allure of the empire to which the city owed its prominence. Rather than being devoid of national feeling, Glaswegian civic pride interacted with an imperial British nationalism. It was as part of the United Kingdom that Glasgow partook in the empire, and through a nationalism which cherished queen and empire, industry and history that Glasgow City Chambers became an 'imperial' building. The local identification with empire could be articulated much more explicitly in relation to the political community of the United Kingdom and the queen than in relation to the local industries that had put Glasgow on the map in the first place. Save for the constant but obligatory references to shipbuilding, the economic link between the city and the empire remained quite implicit. In contrast, the Jubilee Pediment and the opening by Victoria explicitly celebrated the political links in imperialist terms, mainly in relation to Queen Victoria as head of the nation, kingdom and empire.

The harmony and loyalty that this political imagination rested on also extended inwards to Glaswegian society itself. Glasgow's imperial role could only be credible if its own house was in order first. This was the message conveyed by the spandrel sculpture and the profession of loyalty that was the 1883 trades' procession. The city's trades and workers were made part of the idealized vision of the city, but in selective ways that emphasized hierarchy and respectability. Empire influenced the way in which urban social divisions were imagined, and vice versa.

Glasgow City Chambers show that in the European metropoles, identifications with empire not only existed on the national level but also on the urban and local level. This did not only involve the city's own relations to the empire, as could perhaps be expected in the case of important port cities that derived their identities from their overseas connections. Civic pride could also centre on the local community's position as an inseparable part of the empire in a more political sense. This also means that in an architectural sense there were a greater number of local public buildings related to imperialism than capital cities' ministries and national monuments. Local monuments and seats of government are also relevant, as are semi-public buildings with important economic functions such as exchanges, banks and port authority offices.

Finally, as described in the epilogue, the City Chambers formed the culmination of the 'second city' image of Glasgow. This means that the building radiates Victorian confidence and exuberance, but implies as well that this image would start to wane as soon as it was completed. The twentieth-century rise of the Labour party in Glasgow marked the advent of one new image of the city, and the twenty-first-century rise of the Scottish National party that dethroned 
Labour marked another. Conceived as a symbol for Glasgow's proud position in the United Kingdom and its empire, the City Chambers might seem somewhat ill-suited for this new situation. However, as shown in the epilogue, the political sentiments that fuelled this recent transition are rooted in Glasgow's history just as deep, underneath the imperial veneer.

Cite this article: Groten M (2021). Glasgow's new town hall: imperialism, nationalism and civic pride, 1877-1889. Urban History 48, 644-662. https://doi.org/10.1017/S096392682000053X 